\title{
English and the politics of knowledge
}

John Yandell and Monica Brady, with Amy Climpson

\begin{abstract}
:
Drawing on observational evidence of two classes working on Romeo and Juliet, one in England and the other in Palestine, this essay explores the nature of knowledge in relation to English as a school subject. It asserts the importance of paying attention to the resources that students, situated in culture and history, bring with them to the reading of a text. It seeks to contest a set of assumptions about 'powerful' knowledge as universal and transcendent, insisting that classrooms are places where meanings are made, not merely transmitted.
\end{abstract}

Key words: knowledge, curriculum, pedagogy, Shakespeare, meaning-making, English
Newton and Shakespeare are historical figures who made discoveries and wrote plays in their contexts which were very different from ours. But we still go to Shakespeare's plays, and recognize that although they are about a society that we only dimly know about through history books, their characters and relationships articulate for us almost universal truths (Young and Lambert 2014: 65).

The new national curriculum that confronts teachers in England is one that makes explicit from the very start its cultural conservatism. The point of a curriculum, it announces, echoing Matthew Arnold, is to introduce children and young people to 'the best that has been thought and said' (DfE 2014: 6; Arnold 1869/1993: 190). For English as a school subject, what this means is a curriculum that, more than any of the previous four versions (DES/Welsh Office 1990; DfE/Welsh office 1995; DfEE 1999; QCDA 2008), promotes an English (or sometimes 'British') literary heritage and the virtues of Standard English.

There is much to be said about what this curriculum excludes and marginalises, about its casual dismissiveness of difference (different dialects, different identities and cultures, different literary traditions, different forms of textuality), and about its resolute refusal to contemplate the fact that literate practices in the world have 
changed, diversified, multiplied somewhat since 1870. In the world, new media technologies have enabled fundamental changes in practices of representation and communication; in the new curriculum, not so much.

In this essay, however, we want to explore not what is conspicuous by its absence from the new curriculum but rather what would appear to lie at its centre. We focus on Shakespeare. Much of what follows is concerned with two very different classes and their very different experiences of Romeo and Juliet. Our interest is less in curriculum as policy, in and of itself, and more in what Douglas Barnes called the 'enacted curriculum':

When people talk about the school curriculum they often mean what teachers plan in advance for their pupils to learn. But a curriculum made only of teachers' intentions would be an insubstantial thing from which nobody would learn much. To become meaningful a curriculum has to be enacted by pupils as well as teachers, all of whom have their private lives outside school. By enact I mean come together in a meaningful communication, talk, write, read books, collaborate, become angry with one another, learn what to say and do, and how to interpret what others say and do (Barnes 1976:14).

In England nowadays, as in much of the Anglophone world, the planned curriculum may owe as much to politicians' intentions as to teachers', but Barnes' insistence on the importance - and the messy complexity - of what happens in classrooms remains as relevant today as it was forty years ago.

In attempting to describe something of what happened in two classes' encounters with Romeo and Juliet, we want to make three interrelated arguments. The first is, quite simply, that it vital to remain attentive to the local, the particular, to the differences that are instantiated in classrooms and to the different meanings that are made by individual students and in the interactions among students and their teachers. We are committed to narrative modes of inquiry into practice, because such professional storytelling provides a means of speaking back to the powerful discourses of accountability (high-stakes testing, inspections, league tables and so 
on) that operate in such a way as to deny the significance of the local, the particular (Burgess and Hardcastle 1991; Doecke 2004; Doecke and Delandshere 2007, Doecke and McClenaghan 2011; Miller 1995; Parr 2010; Parr, Doecke and Bulfin 2015). The second is that it is a mistake to respond to the imposition of a culturally conservative curriculum by suggesting that canonical literature is intrinsically inaccessible to certain groups of students (see, for instance, Stevens 2014). It seems to us that this response is unhelpful, in that it appears to accept a deficit view of such students. The third is that the view of knowledge presented by the architects and supporters of such culturally conservative curricula is a fundamentally inadequate one.

The first and second arguments will be made through the narratives of classroom practice that follow. It is necessary, though, to say something more about the question of knowledge and the idea of a 'knowledge-led curriculum' (Young and Lambert 2014: 34). ${ }^{1}$ In this model, knowledge - the formal, organised knowledge of disciplines, and by extension of school subjects, is entirely distinct from the category of experience - in other words, the kinds of knowledge that learners might acquire, or have already acquired, outside school (ibid.: 13, 98). School knowledge is transcendent: that is, it transcends the local and the contingent - and its acquisition is what might enable the learners, too, to transcend their immediate circumstances. It is 'better knowledge' (ibid.: 173) than the knowledge that students bring with them. Schooling is not about the production of knowledge but about its transmission and communication (ibid.: 76, 163) and it is subject knowledge that 'provides teachers with the basis of their authority over pupils' (ibid.: 102). Powerful knowledge, then, stands outside the learner, an entity to which the learner is given access in and through the processes of schooling.

What this entails, in relation to subject English and, more particularly to the category of the literary, is made explicit in the quotation from Young and Lambert with which we opened this essay. If school knowledge is transcendent, and the curriculum is intended to introduce learners to 'the best that has been thought and said', it might seem logical to assume that the place of literature within such a curriculum is to 
offer 'almost universal truths' (ibid.: 65). So, is this what Romeo and Juliet offered to our two classes?

In what follows, we offer two stories. The first centres on a single lesson, observed by John in his role as a university tutor working with Amy, at the time a student on a pre-service teacher education course; the lesson took place in a school in a small town in Essex. The second is of a sequence of lessons in a school in Palestine, lessons that were planned and taught by Monica in collaboration with another colleague, Victoria.

\section{Why the haste? Romeo and Juliet in Essex [JOHN $]^{2}$}

The lesson took place in May 2014, towards the end of Amy's second and final practicum, at a non-selective mixed secondary school in a small town in Essex. The Year 7 class (11- and 12-year-olds) was in the midst of a unit of work that had been presented as an introduction to Shakespeare. Amy had been given considerable latitude as to how to organise this introduction and had decided to focus on a single play, Romeo and Juliet.

At the start of this lesson, Amy announces that we will be considering romantic and parental love, and how parental love changes in the course of the play. She encourages students to share their understanding of these terms and relate them to what they know of the play thus far. Tommy ${ }^{3}$, a boy on the far side of the classroom from where I am sitting, provides a definition of parental love and suggests that this is represented in the play in the feelings that the Nurse displays towards Juliet. Amy asks students to recall Lord Capulet's first appearance. Kerry, a girl near the front of the room, remembers that he had said something about Juliet not being ready to marry - that she needed to wait another couple of years. Accepting this, Amy indicates that Capulet's position was at variance with the societal norms in operation at the time of the play's production: Juliet is nearly fourteen, and it was common, announces Amy, for girls as young as twelve to be married. 
What might this first pedagogic sequence suggest about what is entailed in an introduction to Shakespeare as it is being accomplished through the class's shared exploration of Romeo and Juliet? There is the indication that the play might be investigated by mapping certain categories of relationship or interpersonal feeling (romantic and parental love) onto the interactions between characters. This, in turn, is predicated on the assumption that exploring the play might involve a consideration of individual characters and their interactions with other characters.

What is clear, though, both from Amy's plan and from what happens next in the lesson, is that she has other, and rather different, pedagogic objectives in mind. If her students are being introduced to Shakespeare, they are also being inducted into particular ways of doing English, particular ways of reading and analysing text.

Amy presents two quotations from the play and announces that the students will be working in pairs to analyse one or other of them. First, though, Amy will model this process of analysis by working with the whole class on another quotation ('O she doth teach the torches to burn bright!'). Students recognise that this is Romeo, talking about Juliet. They are keen to share their ideas: Obi wonders if warmth might be associated with kindness, with being loving; Kerry asks, 'Isn't Romeo basically saying she's hot?' On the board, Amy records these contributions around the quotation, linking them wherever possible with individual words from Romeo's line. She then makes explicit to the class what she has been doing: she emphasises that this involves a process of grasping the meaning of the whole quotation first and then 'using a magnifying glass to look at a single word.' Having checked that students know what they have to do (all but two of the class indicate that they are confident about this), Amy gives them ten minutes to conduct a similar analysis on their allotted quote, then chooses Edgar to come to the front to show how he has annotated 'sun' in the 'Juliet is the sun.' What Edgar has done, in response to one of the prompts that Amy had provided in setting up the pair annotation task, is to identify the metaphor. What he writes on the board is that Romeo was describing Juliet as a metaphor. Amy amends this to 'Shakespeare uses a metaphor.' Jude 
comes to the front and indicates that 'sun' has connotations of brightness. 'She is the light of his life,' Andrew says. Justin is invited to the board to add his annotation: 'She is that stunning that he is incomplete without her.'

A similar process, involving different students being invited to come to the board to share their annotations, follows for the second quotation ('So shows a snowy dove trooping with crows'). Matt knows a thing or two about the characteristic plumage of doves and crows and about the connotations that tend to cluster around these terms. While the nominated students add their words to the board, the others are encouraged to copy the annotations into their exercise books.

What has been happening in the central section of the lesson, in the modelled annotation of quotations, has been an attempt to induct these Year 7 students into a very particular kind of literary (and literacy) practice. This is designed, I would imagine, as practice for the demands of assessments that are to come: it is preparing students at the start of their secondary schooling for the high-stakes tests that will confront them in future years. Amy is nudging them towards the construction of the PEE (point, evidence, explanation) paragraphs that have become the almost ubiquitous building-blocks of literary critical essays in English schools. The students' work of annotation both directs their attention towards the kind of evidence that they must amass (quotations from the text studied) and represents a first attempt at 'explanation' - the exegesis of what the quotation means and also, more importantly (because this is how the marks are earned), how its meanings are achieved. The practice of annotation looks forward, then, to the final destination of secondary schooling; simultaneously, it looks back towards its origins in the traditions of literary criticism traceable through the New Criticism (Brooks 1956/1968; Wimsatt 1954/1970) to I. A. Richards (1929) and the beginnings of 'practical criticism'. In this tradition, the text is the aesthetic object of study and questions (such as Andrew's, below) that stray beyond the object itself are illegitimate (cf. Knights 1933). It is a tradition of close reading, of attentiveness to the language and form of the text. And Amy's students are beginning to be able to play this game. They begin to notice patterns of imagery, they are learning to zoom in on individual words and consider 
their meaning-potentials. But there are signs that they are uncertain about the rules of this game. In Edgar's case, this uncertainty appears to be an obstacle, getting in the way of his attempts to make meaning of the text: his claim that Romeo is describing Juliet as a metaphor suggests that he hasn't yet found a way of making the metalanguage work for him. He can spot a metaphor at ten paces, but doesn't know what to do with it once it's been identified. Some of his peers (Justin and Kerry as well as Andrew, in the contributions noted above) appear to be more adept at finding apt modern idioms as 'translations' of the Shakespearean phrases than they are at an analysis of the effects of the phrase itself. Their interventions, however, unlike Edgar's, are meaningful: they are drawing on their own linguistic and cultural resources to make sense of the text - and their 'translations' do undoubtedly shed light on the phrases they have been reading.

Amy then announces that we will now turn to focus Act 3 , scene 5 . She provides a brief oral summary of what has happened leading up to this scene (the marriage, the deaths of Mercutio and Tybalt, the banishment of Romeo), to provide a context for the entry of Lord Capulet. Before we can get onto this, though, Andrew has a question: he wants to know why Juliet didn't simply run away with Romeo - why is she still here, in her parents' house, in Verona?

There is, I think, a great deal to be said about Andrew's question. First, perhaps, I should confess that it is precisely the question that occurred to me, at some point in the early 1970s, when I first encountered Romeo and Juliet. I was somewhat older than Andrew, and perhaps that was the reason why, though this seemed a perfectly reasonable question - more than that, it was incomprehensible to me that the two of them didn't just elope - I also knew that this was not the sort of question I was meant to ask about a Shakespeare play, or indeed about any other text within the category of Literature. How I knew this I don't know, but know it I did. At least I think I did. What complicates the memory is that I, like Andrew, first encountered the play in the classroom. But my classroom was rather different from Andrew's, with a different set of social relations. In my boys' grammar school, it would have been frowned on, to say the least, for me to have asked such a question. It would have 
been regarded as doubly inappropriate, both because it signalled a departure from the teacher's announced script for the lesson, thereby contesting the teacher's authority, and because it opened up territory - teenage sexuality and sexual mores that, for all the stereotypes of permissiveness that have subsequently been attached to schooling in the 1970s, certainly was not readily explored in discussions between teachers and pupils in my school. I therefore cannot be sure why I felt I could not ask Andrew's question - whether it was my sense of what was (un)sayable within the discourse of the literary, or within the discourse of schooling - but I knew that I couldn't. It would have raised a laugh (for being doubly transgressive) and landed me in trouble.

It is, in my view, to Amy's credit that Andrew felt he could ask his question in her English class. It is a mark of his confidence and of the pedagogic relations that foster such confidence. His question is also, according to a considerable body of research, something of a rarity: an instance of an authentic, unbidden question, posed by a student in a literature classroom (cf. Nystrand et al. 1997; Miller 2003; Myhill 2006).

Authentic questions matter. They are an index of a different, more dialogic, literature pedagogy, of a different orientation towards knowledge, of the agency of learners in their own learning. And it's possible to see, in this moment in the lesson, a shift from one pedagogy to another, from one conception of the literature classroom to another, from one kind of engagement to another. Or perhaps it's not so much a shift as a widening of the gap between the lesson planned by Amy and the lesson enacted by the students (and Amy). Whatever else, this is not a case of script and counterscript, of two parallel discourses in competition within the same classroom (Gutierrez et al. 1995). For Andrew, the play is the thing; for Amy, the play has some salience, but it is also a vehicle for other pedagogic objectives - for the development of close reading and analysis, and so on.

We move on to reading the scene, with students taking the parts of Capulet, Lady Capulet and Juliet. What is extraordinary (and yet entirely normal) is how Justin grows into Capulet's part. He becomes much more fluent; more than this, he has 
started to inhabit the role - he has become an impatient, insensitive father. Amy pauses the reading. Adam notes that Capulet is threatening to disown Juliet if she doesn't marry Paris. 'How has the relationship changed?' Amy asks. And when she explains what 'carrion' means, there is a spontaneous reaction from the students: 'That's wrong!' The moment is an important one: it shows how involved the students have become, and how they are now in a position where they can not only understand the text but also make judgements about it, about the characters and what is going on.

George wants to know why Juliet doesn't just say no when it comes to saying the vows. Justin asks if Lady Capulet is Juliet's mum. He wants to know why she is not intervening - thus providing an opportunity for Amy to explain a little about patriarchy. As the lesson comes to an end, Amy announces that in the next lesson students will be applying the same sort of close analysis to Capulet's words in this scene.

At the start of the class's next English lesson, Andrew approached Amy. 'I still can't believe what Capulet said to Juliet,' he said. 'If my Dad ever spoke to me like that, I'd knock him out! It is such a disgusting thing to call your daughter who you are supposed to love. And he started out so nice and caring at the beginning.' He continued in the same vein in his assessed assignment:

In terms of "she is the hopefull lady of my eath" Lord Capulet started the play being nice the Juliet and doing the best to find her man but cause she found Romeo she didn't want to get married to Paris so she refused. Because she refused Lord Capulet started to get nasty and childish "Hang the young baggage disobedient wretch" and from their Lord Capulet was probely the nastesty man their in the village. 


\section{Why the haste? Romeo and Juliet in Ramallah [MONICA]}

The series of lessons described here took place during the spring of 2015 in a 10th grade class at a private secondary school in Ramallah. The class was mixed in terms of ability and the students, all with Arabic as their first language, had different levels of competence in English. My role in the school was to teach in partnership with new teachers of English and I shared the planning and teaching of this class with Victoria, a young American. We chose to study the play in the original text rather than using the No Fear edition which has a parallel text in everyday English, and which was used by other sections of the 10th grade.

Before reading the scene (Act 1, scene 2) where Paris asks Lord Capulet for Juliet's hand in marriage, we had asked two students to do an improvisation, focusing on predicting what would happen. Yasmin, as Lord Capulet, thanked a very polite and deferential Maram (Paris) and said he would talk to his daughter and see how she felt about it. In the subsequent discussion, other students wondered if this was realistic. Dina argued very strongly that it wasn't: 'In those days fathers wouldn't give their daughters a choice,' she insisted. Others agreed with her. When they read the scene, therefore, and heard Capulet speak fondly of his daughter, saying, 'Let two more summers wither in their pride/Ere we may think her ripe to be a bride', it wasn't quite what they expected.

In Act 3, scene 4, Lord and Lady Capulet meet with Paris and suggest that he and Juliet should be married in the same week. This later scene, after the death of Tybalt, where Capulet assures Paris - 'I think she will be ruled/In all respects by me. Nay, more, I doubt it not' - is more like the reaction that most of the students predicted. When I ask, 'Why does Lord Capulet decide to arrange the marriage so quickly?' a number of students respond promptly. Most agree with Haya, who says that Lord Capulet just wants Juliet to be happy. Youssef adds that a celebration would make them all feel better after the pain of Tybalt's death. Yasmin argues that Juliet's father only wants to ensure her safety: with the death of Tybalt, the Montagues seem to be in the stronger position. 
The students' mental image of Tybalt is heavily influenced by the opening scene of the Luhrmann version (Luhrmann 1996) and it seems to Yasmin that, with Tybalt felled by the weakling Romeo, the status of the Capulets is threatened. She believes that Capulet feels anger and shame. Laith agrees, suggesting that the Capulets need to add another strong male to the family. Shafiq wonders if it is more to do with Lord Capulet's own happiness, whether he is feeling vulnerable, perhaps wanting to see an heir before he dies. I mention people being more aware of their own mortality when a family member dies, and Leena wonders if Capulet wants to see his daughter happy before his own death. Maram says that a girl should have a man to protect her and, with Tybalt gone, perhaps Capulet wants to ensure that she is safe and looked after.

The only dissenting voice is Jenan's: she feels that Capulet makes the decision for purely social reasons, that it is part of his responsibility as a father to ensure a good marriage for his daughter, that Paris won't stick around indefinitely and that now is as good a time as ever.

A number of things are worth noting in this debate. First, no one questioned the right of Lord Capulet to make decisions for his daughter. They didn't find it unusual for him to assume that his daughter would concur with his wishes, since arranged marriages are common, in some form, at all levels in Palestinian society. He had after all found her a good husband, a kinsman of the prince and, as Capulet says, 'Stuffed, as they say, with honourable parts/Proportioned as one's thought would wish a man.' Second, they were overwhelmingly concerned with Juliet's safety and security. This concern is entirely understandable given their insecure and unpredictable lives. A common refrain here, heard in multiple contexts, is 'Welcome to Palestine'. People will say it genuinely, to visitors in the streets, in shops and restaurants. But they also say it ironically, in frustration at the delays at checkpoints, the non-arrival of items in the post, the failed deliveries, the road closures, the inexplicable arrests. Accepting these consequences of occupation has become a way of life and it is the only one these young people have known. But these unforeseeable difficulties, managed on a day-to-day basis, are a constant reminder 
that Palestinians are not in control of their own state, of their own lives. And it is through the uncertainty of the rules, and the consequences, that power is exercised by the Israeli government. The only place where the rules are explicit, where the power appears to be exercised in their interest, is in the family.

And it is in this context too, that Yasmin's comments about the threats to the public image of the Capulets, and Shafiq's about Lord Capulet feeling vulnerable, have a particular meaning. The extended family unit in Palestine protects individuals and defines identity. As in Shakespeare's Verona, it matters where you belong and your name tells people about your status - and sometimes your political affiliation. Damage to your family reputation could lead an individual to lose influence within the community; but an alteration in the balance of power could also destabilise society as a whole and further divisions render them weaker still. Faced with an enemy that is much more powerful than themselves, Palestinians need to be united, but are politically fragmented and divided in terms of class and religion. Their society, however, is tightly bound together by traditions and commonly-held values that transcend all of these divisions.

Challenging these norms in any way would be fraught with difficulty. Perhaps Romeo and Juliet offers the students the opportunity to look at a parallel situation, at a safe distance, enabling them to explore the issues in a way that might not otherwise be possible.

We ask three students to improvise the discussion between Juliet and her parents about her marriage to Paris before we read the scene (Act 3, scene 5). Sabri, who volunteers to play Juliet, attempts to subvert the exercise by starting to sing 'I feel pretty' from West Side Story. The class respond by cheering and laughing, but then Shafiq comments that Juliet would behave in entirely the opposite way. The roleplay has the desired effect of making them think.

The behaviour of Lord Capulet in this scene shocks the students. The discussion lasts over several lessons. In one lesson, we read and discuss as a class the dialogue 
between Juliet and her mother, then Juliet's meeting with both parents. In the second lesson, students divide into two groups, each taking on the role of director, telling the actors in detail how to play the scene. This task draws into activity a different group of students and ensures that all fully grasp the significance of what takes place. Finally, we watch Luhrmann's interpretation of the scene, where the director chose to have Capulet attack both his wife and daughter in a brutal way, substituting blows for the violent words of the original play.

I ask the students which was more effective. Marwan argues that the words are much more effective since the harsh things you say to someone last a lot longer than blows. Nada says that this is a film, offering the possibility of drama through action, and the director has to think of the audience and how they would respond. Shafiq says that when we read the play we imagine it the way it would be if we were in it, the way each independent person would imagine it. In the film performance, on the other hand, everyone sees only one thing - so the director has to make it appeal to all. Dina says that this is the kind of thing that audiences expect; they don't have the patience for longer speeches without action. Haya feels that the physical fight makes us realise how serious the situation is. Maram speaks about the importance of gesture, of facial expression, and refers to Charlie Chaplin and how people were entertained by his films even though they had no words. Samar sums up the debate by agreeing with Marwan that the words are important for Juliet, and for us as readers to imagine how we would feel in her shoes, but that for a film audience, the physical violence is more shocking.

In studying the scene, the students constantly came back to whether Capulet's attitude to his daughter was normal for the time. It's hard to figure out how much of this was to do with curiosity about the past, about what life was like in Shakespeare's time, and how much their attending to these issues actually enabled them to talk and think about now.

To encourage students to reflect on the play as a whole, we gave them a 'free write' exercise, offering four quotes from the play as a stimulus and allowing them to write 
about whatever came into their minds. The responses, from boys as well as girls, indicated that the position of women in their own and neighbouring countries is a source of concern for them. In Palestine, women have, in the past, taken a leading role in the struggle against Israel. The tightening of Israel's hold, its increasing encroachment on Palestinian lands and the impoverishment of the Palestinian economy as a result of neo-liberal reforms, have diminished the capacity of the people to resist. One consequence of this is increasing unemployment in Palestine, with the percentage of women in work being the lowest in the world. Another is the increasing conservatism of society. Both have affected the overall position of women; it is possibly for this reason that students voiced so clearly their enjoyment of the play, its relation to their own lives and their ability to speak in class and hear the views of their peers.

\section{English as a site of development and contestation}

For Amy's students in Essex as for Monica's in Ramallah, the characters and relationships represented in Romeo and Juliet really do not seem to have 'articulated ... almost universal truths' (Young and Lambert 2014: 65). What is salient in the responses of the students in both classes is the local, the particular. In both cases, too, the particular is not idiosyncratic or merely individual. How these students read and respond to the text is a product of culture and history - of different, and specific, cultures and histories. The sign, Romeo and Juliet, takes on different meanings in these two classrooms. So, too, do other signs: 'mother', 'father', 'daughter', 'family', every bit as much as 'revenge', 'loyalty' or 'society', simply do not mean the same thing in Ramallah as they do in Essex. (More than this: they do not mean the same in Essex as they would in a school thirty miles to the west, in Tower Hamlets or Newham.)

As Vygotsky observed:

The development of the concept, 'brother,' did not begin with a teacher's explanation or with a scientific formulation. This concept is saturated with the child's own rich personal experience (Vygotsky 1987: 178). 
This rich personal experience is not reducible, however, to the child's first-hand, lived experience of real brothers. The concept of brother develops at least as much from all the brothers met in stories, in whatever form those stories are passed on. The students' different readings of Romeo and Juliet arise out of different experiences of how families operate, what families are, but also out of different prior experiences of how families are discursively produced: the different readings are products of both extratextual and intertextual knowledge (as, perhaps, all readings are and must be).

Experience, in these accounts, is thus not that which must be displaced or abandoned in favour of the 'better knowledge' that the curriculum provides. On the contrary, experience is constitutive of the reading that is enacted in the classroom: it is what enables Andrew (in Amy's class) or Jenan (in Monica's) to make (different) sense of Lord Capulet's relationship with Juliet, the one to see Capulet as a monster ('the nastyest man their in the village'), the other to construe him as a rational social actor.

We think that it is vitally important to acknowledge the constitutive power of experience (in this more capacious sense of the term, encompassing culture and history) if we are to provide an adequate account of the readings of Romeo and Juliet that were accomplished in these two classrooms. But we also recognise that there is a danger in this emphasis, in that it might suggest that experience determined the readings that were produced, and hence fail to acknowledge the agency of the students who were constructing their very different readings of the text.

In Amy's lesson, Andrew does not arrive at Romeo and Juliet with a fully articulated position on the role and responsibilities of fathers. In his angry reaction to Capulet, he can be seen working out what he thinks fathers should do, how fathers should behave. He develops an ethical position in making sense of the text, and the text becomes a tool that enables the development of his thinking. The work that he does 
is cognitive and emotional: intellect and affect are not neatly separable. Likewise, as Monica's account above indicates, her students' discussion of Capulet's motives and behaviour enables them to explore signs such as 'father' and 'family' to make explicit assumptions and in so doing to hold these assumptions up to scrutiny. Here, the students can with legitimacy explore whether fathers, however good their intentions, have the right to make decisions for their daughters, and whether the enforcement of a father's will is acceptable as long as it is done without overt aggression.

The 'social multiaccentuality of the ideological sign' (Vološinov 1929/1986: 23) is apparent in both these classrooms: 'it is thanks to this intersecting of accents that a sign maintains its vitality and dynamism and the capacity for further development' (Vološinov, ibid.). Vološinov's emphasis on dynamism, on the remaking of the sign in the clash of different accents, helps us to make sense of how Romeo and Juliet was being read in these classrooms, and perhaps even of why it was worth reading. The pedagogic relations and practices that are evident in both classrooms are enabling conditions for this orientation towards the production of knowledge. (And there is a sharp contrast between these pedagogies and the ones that John experienced in his own schooldays.) Truth, for Amy's as for Monica's students, is not some pre-existent entity (the best that has been thought or said), nor is it universal; on the contrary, it is inseparable from the concrete, from particular struggles for and over meaning. ${ }^{4}$

These struggles are to do with what Romeo and Juliet means now, in particular places and in the interactions of particular learners. Meanings are made, not merely transmitted. In both classrooms, though, there are questions about the historical dimension of the text. These questions are more prominent in Monica's classroom. Her students are more aware of distance, historical as well as cultural and linguistic, and readier to pose questions about the context of the play's first production and the social world that it represents. But this aspect is also opened up by Andrew's question - why didn't Juliet just run away with Romeo?

We are reminded of Tony Burgess's insistence on: 
... the centrality of concepts to reading and to work with texts. In teaching texts like Great Expectations and relating these to their sociocultural background, concepts of the past and poverty and class are central. How children handle such historical and social concepts are fundamental to their reading of the novel. More generally, much of the work we want to do on critical literacy or in comparing texts of different kinds or in addressing media production challenges and develops the conceptual powers of students. ... Vygotskyan theory reminds us, as teachers, that English, no less than other curriculum areas, works with students' concepts and helps to form them. (Burgess 2007: 31)

There is, in our view, a world of difference between Burgess's view of teachers working with students' concepts and the model of a 'knowledge-led' curriculum: a difference in how the teacher's role is conceptualised, in whose concepts are being worked on, and in the emphasis on the dynamic, shifting nature of concepts themselves. In Monica's and Amy's classrooms, students are wrestling with historical, social and ethical concepts as they interrogate the text that they are reading. Their concepts are developing through this process, in ways that involve continuous dialectical movement from past to present, from text to lifeworld (and back again).

Young and Lambert (2014: 65) suggest that Shakespeare's plays are 'about a society that we only dimly know about through history books.' But this won't do at all. Reading other texts can, of course, enrich and complicate the meanings that we make from Romeo and Juliet. It makes a difference if we know that one of Shakespeare's sources for the play, Arthur Brooke's (1562) The Tragicall History of Romeus and Juliet, takes a much more straightforward, censorious attitude to the lovers, representing them as culpable for their desire and for their failure to respect parental authority. But knowing this, or knowing more about other sixteenth-century representations of family, sex, marriage, of patriarchal power and class relations, cannot resolve Andrew's question, nor those of Monica's students. Romeo and Juliet problematises these concepts, making them the contested objects of dramatic inquiry: multiaccentuality was as much a condition of the text's first production as it is of its remaking today, every time it is read, differently, in different classrooms. 


\section{$\underline{\text { References }}$}

Arnold, M. (1869/1993). Culture and Anarchy and other writings. Cambridge:

Cambridge University Press.

Barnes, D. (1976). From Communication to Curriculum. Harmondsworth: Penguin.

Brooks, C. (1956/1968). The Well Wrought Urn: Studies in the Structure of Poetry. London: Methuen.

Burgess, T. (2007). The picture of development in Vygotskyan theory: renewing the intellectual project of English. In V. Ellis, Fox, C., \& Street, B. (eds), Rethinking English in Schools: towards a new and constructive stage (pp. 17-31). London \& New York: Continuum.

Burgess, T., \& Hardcastle, J. (1991). A Tale of Three Learners: The Cultural Dimension of Classroom Language Learning. In P. Gordon (Ed.), Teaching the Humanities (pp. 36-49). London: Woburn Press.

DES [Department of Education and Science]/Welsh Office. (1990). English in the National Curriculum. London: HMSO.

DFE [Department for Education]/Welsh Office. (1995). English in the National Curriculum. London: HMSO.

DfE [Department for Education]. (2014). The national curriculum in England: Framework document.

https://www.gov.uk/government/uploads/system/uploads/attachment data/f ile/381344/Master final national curriculum 28 Nov.pdf

DfEE (Department for Education and Employment). (1999). The National Curriculum. London. 
Doecke, B. (2004). Accomplished story telling: English teachers write about their professional lives (The Standards for Teachers of English Language and Literacy in Australia project). Teachers and Teaching: theory and practice, 10(3), 291305.

Doecke, B., \& Delandshere, G. (2007). Editorial: what counts as research in English literacy education? English Teaching: Practice and Critique, 6(3), 1-3. Parr, G. (2010). Inquiry-based Professional Learning: speaking back to standards-based reforms. Teneriffe, Queensland: Post Pressed.

Doecke, B., \& McClenaghan, D. (2011). Confronting Practice: classroom investigations into language and learning. Putney, NSW: Phoenix.

Gutierrez, K., Rimes, B., \& Larson, J. (1995). Script, Counterscript, and Underlife in the Classroom: James Brown versus Brown v. Board of Education. Harvard Educational Review, 65(3), 445-471.

Hirsch, E. D. (1987). Cultural Literacy: What Every American Needs to Know. Boston: Houghton Mifflin.

Hirsch, E. D. (1996). The Schools We Need and Why We Don't Have Them. New York: Doubleday.

Hirsch, E. D. (2006). The Knowledge Deficit: Closing the Shocking Education Gap for American Children. Boston \& New York: Houghton Mifflin.

Knights, L. C. (1933). How Many Children Had Lady Macbeth? An essay in the theory and practice of Shakespeare criticism. Cambridge: The Minority Press.

Luhrmann, B. (1996) William Shakespeare's Romeo + Juliet. USA: Bazmark Films/Twentieth Century Fox. 
Miller, J. (1995). Trick or Treat? The Autobiography of the Question. English

Quarterly, 27(3), 22-26.

Miller, S. M. (2003). How Literature Discussion Shapes Thinking: ZPDs for Teaching/Learning Habits of the Heart and Mind. In A. Kozulin, Gindis, Boris, Ageyev, Vladimir S, Miller, Suzanne M. (Ed.), Vygotsky's Educational Theory in Cultural Context (pp. 289-316). Cambridge: Cambridge University Press.

Myhill, D. (2006). Talk, talk, talk: teaching and learning in whole class discourse. Reseach Papers in Education, 21(1), 19-41.

Nystrand, M., Gamoran, A., Kachur, R., \& Prendergast, C. (1997). Opening Dialogue: understanding the dynamics of language and learning in the English classroom. New York \& London: Teachers College Press.

Parr, G., Doecke, B., \& Bulfin, S. (2015). Stories: A Common Currency. Changing English, 22(2), 135-141.

QCDA [Qualifications and Curriculum Development Authority]. (2008). The National Curriculum. London: Retrieved from http://curriculum.qcda.gov.uk/keystages-3-and-4/subjects/key-stage-4/english/programme-ofstudy/index.aspx?tab=1.

Richards, I. A. (1929). Practical Criticism: a study of literary judgment. London: Routledge \& Kegan Paul.

Stevens, M. (2014). Michael Gove: Reconsider the changes to English Literature GCSE. from https://www.change.org/p/nicky-morgan-mp-reconsider-thechanges-to-english-literature-gcse

Vološinov, V. N. (1929/1986). Marxism and the Philosophy of Language (L. Matejka, \& Titunik, I.R., Trans.). Cambridge, Mass. \& London: Harvard University Press.

Vygotsky, L. S. (1987). Problems of General Psychology, including the Volume Thinking and Speech (N. Minick, Trans. Vol. 1). New York \& London: Plenum. 
Wimsatt, W. K. (1954/1970). The Verbal Icon: Studies in the meaning of poetry. London: Methuen.

Young, M., \& Lambert, D. (2014). Knowledge and the Future School: Curriculum and Social Justice. London: Bloomsbury.

${ }^{1}$ Young and Lambert distinguish their version of a knowledge-led curriculum from the current English national curriculum and form that which is proposed by E.D. Hirsch $(1987,1996,2006)$ on the grounds that Hirsch's model of 'core knowledge' is solely concerned with content, whereas their model also privileges concepts and activities (Young and Lambert 2014: 68). We focus here on Young and Lambert's version because it is, in our view, the most coherent and most cogently argued version of a knowledge-led curriculum. We disagree with it, but we think it is worth taking seriously.

${ }^{2}$ We are very grateful to Amy Climpson for her permission to write about this lesson and for supplying us with information about Andrew's subsequent responses, in speech and in writing, to Capulet's treatment of Juliet.

${ }^{3}$ The names of all school students have been changed to culturally appropriate pseudonyms.

${ }^{4}$ Arnold argued that 'the best which has been thought and said in the world' had the capacity to act as an intellectually liberating resource, the means by which we might turn 'a stream of fresh and free thought upon our stock notions and habits, which we now follow staunchly but mechanically' (Arnold 1869/1993: 190). Though we might want to quarrel with Arnold's location of transformational power within the text itself (rather than in the readers' dialogue with the text and with each other), and with his simple binary opposition of the 'fresh' and the 'stock', we recognise that he was, at least, envisaging some sort of transactional process in which the text becomes a tool for (re-)thinking current problems. No such appreciation of the complex and contingent interactions between texts and readers would appear to inform the national curriculum into which Arnold's words have been coopted. 